\title{
POLITIK HUKUM PEMERINTAHAN DESA DI INDONESIA
}

\author{
M. Iwan Satriawan \\ Dosen Bagian Hukum Tata Negara Fak. Hukum Universitas Lampung \\ Email : i_santri@yahoo.co.id
}

\begin{abstract}
Abstrak
Tujuan penulisan artikel ini adalah untuk mengetahui arah politik hukum pemerintahan desa. Menggunakan pendekatan sejarah hukum dapat disimpulkan bahwa arah politik hukum pemerintahan desa dari tahun ke tahun telah menunjukkan kearah yang lebih baik. Sebagai bagian sistem pemerintahn terkecil desa telah memiliki peraturannya sendiri yaitu melalui Peraturan Pemerintah Nomor 72 Tahun 2005 tentang desa. Hal ini adalah sebagai dasar bahwa sistem organisasi desa langsung dibawah bupati atau walikota.
\end{abstract}

\section{Kata kunci : Politik Hukum dan Pemerintahan Desa}

\section{Pendahuluan}

Istilah "Desa" secara etimologis berasal dari kata "swadesi" bahasa Sansakerta berarti wilayah, tempat atau bagian yang mandiri dan otonom. ${ }^{1}$ Istilah desa sendiri sangat beragam di berbagai tempat di Indonesia. Desa hanya dipakai dalam masyarakat pulau Jawa, Madura dan Bali. Sedangkan masyarakat Aceh menggunakan nama Gampong atau Meunasah, masyarakat Batak menyebutnya dengan Kuta atau Huta, didaerah Minangkabau disebut dengan Nagari,kemudian di Lampung disebut dengan dusun, pekon atau tiuh. Dalam kamus Besar Bahasa Indonesia kata "desa" diartikan sebagai kesatuan wilayah yang dihuni oleh sejumlah keluarga yang mempunyai sistem pemerintahan sendiri. $^{2}$

\footnotetext{
${ }^{1}$ P.j Zoetmulder dalam Ateng Syarifuddin, 2010, Republik Desa, Alumni: Bandung, hlm. 2.

2 Tim Penyusun kamus Pusat Pembianaan dan Pengembangan Bahasa, 1995, Kamus Besar Bahasa Indonesia Cet.VII, Balai Pustaka. Jakarta. hlm.226.
}

Sedangkan dalam istilah lain desa diartikan adalah suatu kesatuan masyarakat hukum yang mempunyai susunan asli berdasarkan hak asal usul yang bersifat istimewa. Landasan pemikiran dalam mengenai pemerintahan desa adalah keanekaragaman, partisipasi, otonomi asli, demokratisasi dan pemberdayaan masyarakat. $^{3}$

Keberadaan desa sebagai satu kesatuan masyarakat hukum memberi pemahaman yang mendalam bahwa institusi desa bukan hanya sebagai entitas administratif belaka tetapi juga entitas hukum yang harus dihargai,diistimewakan, dilindungi dalam struktur pemerintahan di Indonesia.

Hal ini yang kemudian tertuang dalam UUD 1945 pasal 18 B ayat (2) yang menyatakan: Negara mengakui dan menghormati kesatuan-kesatuan masyarakat hukum adat beserta hakhak tradisionalnya sepanjang masih hidup dan sesuai dengan perkembangan masyarakat dan

3 HAW. Widjaja, 2012, Otonomi Desa (Merupakan Otonomi yang Asli, Bulat dan Utuh), Rajawali Press: Jakarta, hlm.3 
prinsip Negara Kesatuan Republik Indonesia, yang diatur dengan undang-undang. Dari pemahaman pasal 18 B ayat (2) UUD 1945, bahwa desa diartikan bukan saja sebagai kesatuan masyarakat hukum adat, tetapi juga sebagai hirarki pemerintahan yang terendah dalam NKRI. $^{4}$

Secara teoritik dan praktik, terdapat perbedaan antara pemerintah dengan pemerintahan. Pemerintahan adalah bestuurvoering atau pelaksanaan tugas pemerintah, sedangkan pemerintahan ialah organ atau alat/aparat yang menjalankan pemerintahan ${ }^{5}$. Dalam istilah lain pemerintahan dan pemerintah dalam masyarakat secara umum diartikan sama, dimana kedua kata tersebut diucapkan bergantian (pemerintah atau pemerintahan). Sebutan kedua kata atau istilah tersebut menunjuk pada penguasa atau pejabat. Mulai dari Presiden hingga Kepala Desa, artinya semua orang yang memegang jabatan disebutlah pemerintah atau pemerintahan, tetapi orang yang bekerja di dalam lingkungan pemerintah atau pemerintahan disebut orang pemerintah(an). ${ }^{6}$

Menurut Ramlan Subekti, pemerintahan mempunyai pengertian dalam arti luas dan sempit. Pemerintahan dalam arti luas berarti seluruh fungsi negara seperti legislatif, eksekutif dan yudikatif.

\footnotetext{
${ }^{4}$ Khairuddin, 2011, Dekonstruksi Politik Hukum Otonomi Desa Dalam Peraturan Perundang-undangan Di Indonesia, Ringkasan disertasi tidak diterbitkan.

5 Ridwan H.R sebagaimana dikutip oleh Yulia Netta dan M.Iwan Satriawan, 2013, Ilmu Negara (Dasar-Dasar Teori Bernegara), PKK-PUU F.H Unila:Bandar Lampung, hlm.70

${ }^{6}$ Didik Sukaryono, 2010, Pembaharuan Hukum Pemerintah Desa, Setara Press: Malang, hlm 57
}

Sedangkan pemerintahan dalam arti sempit meliputi eksekutif saja. ${ }^{7}$

Dalam literature yang lain Montesquie mengartikan pemerintahan dalam arti luas meliputi: pembentukan undangundang (la-puissance legislative); pelaksanaan (la-puissance executive); dan peradilan (lapuissance de juger). Ajaran Montesquieu ini dikenal dengan ajaran tentang pembagian kekausaan negara yang popular disebut dengan "trias politika". 8

Seiring dengan bergulirnya reformasi 1998, yang mana salah satu tuntutannya adalah diberlakukannya otonomi daerah secara luas, maka telah terjadi pergeseran dalam dinamika pemerintahan di Indonesia khususnya mengenai desa.Jika masa sebelum reformasi bersifat sentralistik maka setelah reformasi menjadi desentralisasi. Bergulirnya otonomi daerah tersebut yang artinya daerah kebebasan dan kemandirian dari satuan pemerintahan lebih rendah untuk mengatur dan mengurus sebagian urusan pemerintahan. $^{9}$ Kebebasan dan kemandirian dalam otonomi daerah bukan berarti kemerdekaan melainkan kebebasan dan kemandirian dalam ikatan negara kesatuan.

Hal ini membuktikan bahwa keberadaan otonomi daerah sebagaimana pernyataan Bagir Manan tersebut diatas, tidak

\footnotetext{
${ }^{7}$ http://kanekzoke.blogspot.com/diakses pada tanggal 14 Desember $2011 \mathrm{hlm} 1$

${ }^{8}$ Sadjijiono, 2008, Memahami Beberapa Bab Pokok Hukum Administrasi, Laksbang Pressindo:Yogyakarta, hlm.42.

9 Bagir Manan,1993, Perjalanan historis Pasal 18 UUD 1945,Uniska: karawang, hlm 30
} 
kemudian mengartikan bahwa pemerintah desa lepas mandiri atau kemudian menjadi negara bagian, namun tetap dalam koridor asas desentralisasi, dekonsentrasi dan tugas pembantuan sebagaimana asas otonomi daerah yang di anut di Indonesia.

Dengan demikian, pertama, Bagaimanakah dinamika perubahan politik hukum pemerintahan desa di Indonesia?, kedua Bagaimanakah arah politik hukum pemerintahan desa di Indonesia sekarang?

\section{Pembahasan}

\subsection{Konsep Dasar Pemerintahan Desa}

Konsep pemerintahan dalam arti luas sebagaimana dikemukakan oleh ramlan Subekti yang mengacu pada organ-organ negara semacam eksekutif, legislative dan yudikatif sebagaimana konsep trias politika. Namun berbeda halnya dengan Indonesia yang menggunakan konsep Panca Praja yaitu adanya lembaga Presiden sebagai representasi eksekutif, DPR, DPD dan MPR sebagai representasi legislative, M.A dan M.K sebagai representasi yudikatif ditambah BPK (Badan Pemeriksa Keuangan) yang berdiri sendiri sejajar dengan ketiga lembaga tinggi negara tersebut.

Dari fenomena tersebut, maka dapat dikatakan bahwa pemerintah menyangkut organ atau kelembagaan yang memiliki tugas dan kewenangan. Sedangakan kata-kata pemerintahan dapat diartikan sebagai penyelenggaraan tugas dan kewenangan oleh organ atau lembaga yang memiliki tugas dan kewenangan.

Perumusan formal desa dalam UU No 5 Tahun 1979 tentang
Pemerintahan Desa adalah sebagai berikut :

$\begin{array}{lrr}\text { “...suatu wilayah } & \text { yang } \\ \text { ditempati } & \text { oleh } & \text { sejumlah } \\ \text { penduduk sebagai } & \text { kesatuan } \\ \text { masyarakat } & \text { termasuk di } \\ \text { dalamnya kesatuan masyarakat } & \text { mukum yang mempunyai } \\ \text { organisasi } & \text { pemerintahan } \\ \text { terendah langsung } & \text { dibawah } \\ \text { Camat dan } & \text { berhak } \\ \text { menyelenggarakan } & \text { rumah } \\ \text { tangganya sendiri dalam ikatan } \\ \text { Negara Kesatuan Republik } \\ \text { Indonesia..." } \\ \text { Sedangkan dalam UU No 22 }\end{array}$
Tahun 1999 tentang Pemerintahan Daerah, desa diberi pengertian sebagai:

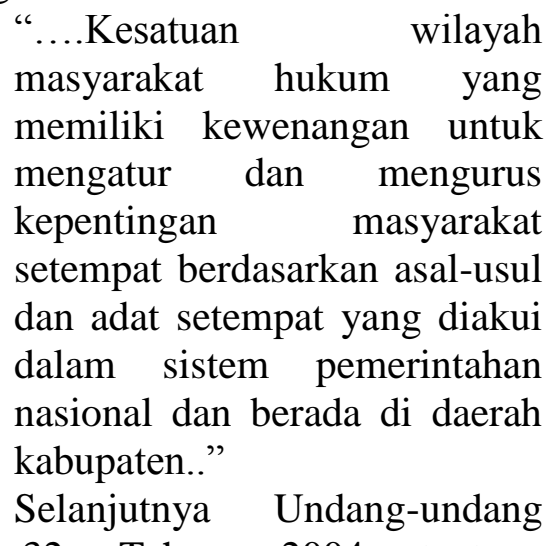
No 32 Tahun 2004 tentang Pemerintahan Daerah Pasal 1 angaka (12) desa dikatakan sebagai:

".....kesatuan masyarakat hukum yang memiliki batasbatas wilayah yang berwenang untuk mengatur dan mengurus kepentingan masyarakat setempat, berdasarkan asalusul dan adat istiadat setempat yang diakui dan dihormati dalam sistem Pemerintahan Negara Kesatuan Republik Indonesia.."

Sedangkan pengertian pemerintahan desa menurut Peraturan Pemerintah Republik Indonesia No 72 Tahun 2005 
Tentang Desa terutama pada pasal 1 angka (6) adalah penyelenggaraan urusan pemerintahan oleh pemerintah desa dan Badan Permusyawaratan Desa dalam mengatur dan mengurus kepentingan masyarakat setempat berdasarkan asal-usul dan adat istiadat setempat yang diakui dan dihormati dalam sistem Pemerintahan Negara Kesatuan Republik Indonesia.

Dari uraian tersebut diatas, menurut Didik Sukriono dalam bukunya pembaharuan hukum Pemerintahan Desa ${ }^{10}$ secara yuridis dan politis terdapat dua konsep desa yaitu, desa yang diakui, yakni desa masyarakat hukum adat yang disebut dengan nama-nama setempat dan desa dibentuk, yakni desa yang diakui oleh pemerintah berdasarkan undang-undang.Artinya desa dipandang sebagai suatu daerah kesatuan hukum dimana bertempat tinggal suatu masyarakat yang berkuasa atau memiliki wewenang mengadakan pemerintahan sendiri.

\subsection{Dinamika Perubahan Politik Hukum Pemerintahan Desa}

Berangkat dari perbedaan pendapat dari para ahli tentang politik hukum, maka Imam Syaukani dan A. Ahsin Thohari menetapkan ruang lingkup atau wilayah kajian politik hukum sebagai berikut: ${ }^{11}$

1. Proses penggalian nilai-nilai dan aspirasi yang berkembang dalam masyarakat oleh penyelenggara negara yang berwenang merumuskan politik hukum;

2. Proses perdebatan dan perumusan nilai-nilai dan

\footnotetext{
${ }^{10}$ Didik Sukriono,Op.Cit.hlm.64.

11 Imam Syaukani, dan A. Ahsin Thohari, 2006, Dasar-dasar Politik Hukum, Raja Grafindo Persada: Jakarta,hlm.51-52.
}

aspirasi tersebut ke dalam bentuk sebuah rancangan peraturan perundang-undangan oleh penyelenggara negara yang berwenang merumuskan politik hukum;

3. Penyelenggaraan negara yang berwenang merumuskan dan menetapkan politik hukum;

4. Peraturan perundang-undangan yang memuat politik hukum;

5. Faktor-faktor yang mempengaruhi dan menentukan suatu politik hukum, baik yang akan, sedang dan telah ditetapkan;

6. Pelaksanaan dari peraturan perundang-undangan yang merupakan implementasi dari politik hukum suatu negara.

Dari ruang lingkup yang diberikan oleh Imam Syaukani dan A.Ahsin Thohari tersebut diatas, maka dinamika perubahan politik hukum pemerintahan desa di Indonesia telah mengalami berbagai macam bentuk sistem pemerintahan. Dari sistem pemerintahan orde lama yang awalnya demokrasi kemudian berubah menjadi otoriter dan pemerintahan orde baru yang otoriter yang selanjutnya digantikan oleh orde reformasi yang demokratis.

Pasang surut ini tidak terlepas dari gaya kepemimpinan dalam mengambil kebijakan. Sebagaimana dikatakan oleh Mahfud M.D konfigurasi politik yang demokratis akan melahirkan produk hukum yang berkarakter responsive atau otonom, sedangkan konfigurasi politik yang otoriter (nondemokratis) akan melahirkan produk hukum yang 
berkarakter konservatif atau ortodoks atau menindas. ${ }^{12}$

\section{Desa di 1945-1949}

Awal-awal kemerdekaan adalah awal yang sulit bagi pemerintahan dwi tunggal SoekarnoHatta dalam melaksanakan pemerintahan sebagaimana amanat UUD 1945. Hal ini disebabkan masih bercokolnya tentara Belanda di beberapa wilayah Indonesia untuk mempertahankan lagi daerah jajahannya. Sedangkan pemerintah Indonesia sudah menyatakan diri kemerdekaannya. Dari agresi militer Belanda ke-1 pada tahun 1946 hingga agresi militer Belanda ke-2 pada 1947 yang berhasil menahan beberapa pemimpin Indonesia semacam Soekarano, Hatta, Agus Salim, Sutan Syahrir ke Brastagi Sumatera Utara.

Namun terlepas dari masa revolusi tersebut, Negara Kesatuan Republik Indonesia yang diproklamasikan pada tanggal 17 Agustus 1945, sejak awal disepakati untuk mendirikan suatu negara yang menganut paham unitaris dengan bersendi desentralisasi.

Sesuai dengan bunyi Pasal 18 UUD 1945 yang bersesuaian dnegan Pasal 1 ayat (1) UUD 1945 yang secara tegas mengehndaki konsep desentralisasi dalam negara kesatuan, tetapi penegasan ini tidak memberikan indikasi bahwa kewenangan otonomi pemerintah daerah bersifat kewenangan negara bagian. Kaidah pasal 18 menegaskan tentang daerah otonom dan istimewa, dibiaskan dengan kaidah penjelasan Pasal 18 dengan menyebut ada

\footnotetext{
${ }^{12}$ Mahfud M.D, 2010, Membangun Politik Hukum, Menegakkan Konstitusi, Rajawali Press:Jakarta.hlm.66
}

wilayah bersifat administrative, disamping daerah otonom dan istimewa. ${ }^{13}$

\section{Desa Masa 1949-1950}

Konstitusi RIS lahir setelah bentuk negara mengalami perubahan dari bentuk negara kesatuan menjadi negara federal hal ini merupakan hasil dari perundingan Renville. Perubahan ini secara langsung turut berpengaruh pada pelaksanaan pemerintahan sampai ke daerahdaerah. Bukan lagi hubungan antara pemerintah pusat dengan daerah melainkan negara federal dengan pemerintah negara bagian dengan pemerintah daerah dibawahnya.

Realiasasi dari amanat dalam konstitusi RIS untuk mengatur hubungan pemerintah negara bagian dengan pemerintah daerah, maka dikelaurkannya UU Negara Indonesia Timur No.44 Tahun 1950 tentang Pemerintah Daerah Negara Timur pada 15 Mei 1950. ${ }^{14}$ Sedangkan untuk wilayah lain dari Republik Indonesia Serikat (RIS) tetap memakai UU No 22 Tahun 1948 khususnya di wilayah negara Republik Indonesia.

\section{Masa 1950}

Keberlakuan RIS yang hanya satu tahun membawa dampak pada

\footnotetext{
${ }^{13}$ Aggusalim Andi Gandjong dalam Didik Sukriono,Op.Cit.hlm.155

${ }^{14}$ Ibid.hlm.157,disini bahkan dijelaskna pula bahwa makna yang termaktub dalam konsideran UU NIT No 44 Tahun 1950 dijelaskna bahwa sangat perlu diadakan perubahan dalam pemerintahan daerahdaerah di Indonesia Timur agar perubahanperubahan itu dapat disesuaikan dengan status negara kesatuan yang segera akan dibentuk.
} 
berubahnya pula UUD RIS. Pergantian dari UUD RIS kepada UUDS berdampak pada perubahan susunan negara federal menjadi negara kesatuan yang berbentuk republic. Perubahan ini membawa konsekwensi makna hukum yang mengatur hubungan antara pusat dan daerah dalam bingkai Negara Kesatuan Republik Indonesia (NKRI).

Dalam UUDS menegaskan landasan hukum pelaksanaan pemerintahan daerah seperti pembagian daerah di Indonesia atas daerah ebsar dan kecil yang berhak mengurus rumah tangganya sendiri, dengan bentuk susunan pemerintahannya ditetapkan dengan undang-undang, dengan memandang dan mengingat dasar permusyawaratan dan dasar perwakilan dalam sistem pemerintahan negara. ${ }^{15}$

Pada Pasal 131 ayat (1) UUDS menyebutkan tentang pembagian daerah Indonesia atas daerah besar dan kecil yang berhak mengurus rumah tangganya sendiri (autonom), dengan bentuk susunan pemerintahannya ditetapkan dengan undang-undang, dengan memandang dan mengingat dasar permusyawaratan dan dasar perwakilan dalam sistem pemerintahan negara.

Kemudian pada Pasal 131 ayat

(2) menyebutkan bahwa kepada daerah diberikan otonomi seluasluasnya untuk mengurus rumah tangganya sendiri. Kemudian pada Pasal 132 juga menyebutkan bahwa kedudukan daerah Swapraja diatur dengan undang-undang dengan ketentuan bahwa dalam bentuk susunan pemerintahannya harus

${ }^{15}$ Ibid.hlm. 157 diingat pula ketentuan dalam pasal 131, dasar-dasar permusyawaratan dan perwakilan dalam sistem pemerintahan negara.

Dari semua pasal-pasal tersebut diatas, tidak menjelaskan secara terperinci pemerintahan desa, namun lebih banyak mengatur tentang daerah-daerah yang diberikan otonomi untuk mengurus rumah tangganya sendiri.

\section{Masa 1959}

Seiring dengan mundurnya bung Hatta sebagai wakil Presiden maka bekahir sudahlah dwi tunggal Soekarno-Hatta dalam memimpin perjalanan bangsa Indonesia yang di proklamasikan pada tanggal 17 Agustus 1945.

Salah satu perubahan yang paling menonjol adalah diberlakukannya Dekrit Presiden 5 Juli $1959 .{ }^{16}$ Perubahan ini membawa konsekwensi terjadinya penyesuaian (perubahan) kembali susunan pemerintahan di daerah dengan susunan menurut UUD 1945.

Hal ini nampak dengan dikeluarkannya Penpres No 6 Tahun 1959 sebagai landasan yuridis penyelenggaraan pemerintahan daerah. Pelaksanaan Penpres ini semakin menunjukkan perubahan politik hukum pada kuatnya intervensi pusat kepada daerah yang dapat dilihat dalam (a) pengawasan atas jalannya pemerintahan daerah;(b) kekuasaan kepala daerah sebagai alat pusat untuk"menangguhkan"keputusan DPRD;dan (c) pengisian jabatan

\footnotetext{
${ }^{16}$ Salah satu isi dekrit Presiden 5 Juli 1959 adalah kembali kepada UUD 1945 dan tidak berlakunya UUD Sementara.
} 
kepala daerah melalui mekanisme pengangkatan.

\section{Masa 1965-1998}

Pasca runtuhnya Soekarno dengan orde lamanya maka dimualailah pemerintahan baru dibawah kepemimpinan Jenderal Soeharo yang biasa disebut dengan orde baru. Melalui TAP MPRS No XXI/MPRS/1966 digariskan politik hukum otonomi daerah yang seluasluasnya disertai perintah agar UU No 18 Tahun 1965 diubah kembali guna disesuaikan dengan prinsip otonomi yang dianut oleh TAP MPRS tersebut.

Dengan kekuatan politiknya yang dominan, pemerintah orde baru kemudian mencabut TAP MPRS No XXI/MPRS/1966 tentang otonomi daerah dan memasukkan masalah tersebut ke dalam TAP MPR No IV/MPR/1973 tentang GBHN yang sejauh menyangkut politik hukum otonomi daerah dengan merubah asasnya dari otonomi nyata yang seluas-luasnya menjadi otonomi nyata dan bertanggung jawab.

Ketentuan ini kemudian dijabarkan lebih lanjut dalam UU No 5 Tahun 1974 dan UU No 5 Tahun 1979 yang melahirkan sentralisasi kekuasaan dan menumpulkan otonomi daerah. Dengan berlakunya undang-undang ini telah melahirkan ketidakadilan secara politik dengan menempatkan kedudukan DPRD sebagai bagian dari pemerintah daerah dan penetapan kepala daerah.Juga ketidakadilan ekonomi dengan banyak kekayaan daerah terserap habis ke pusat untuk kemudian dijadikan alat operasi dan tawar-menawar politik yang akhirnya menimbulkan benih-benih korupsi, kolusi dan nepotisme (KKN).

\section{Masa 1998-2004}

Reformasi 1998 dengan ditandai jatuhnya pemerintahan Soeharto yang telah menguasai negeri ini selama lebih kurang 32 tahun telah membawa angin segar dalam kehidupan demokrasi di Indonesia.

Munculnya ide-ide negara federalis atau yang lebih ekstrim dengan melakukan disintegrasi dari Negara Kesatuan Republik Indonesia jika tidak dilakukan perubahan mendasar khususnya mengenai hubungan pusat dan daerah.

Hal ini kemudian direspon dengan mengeluarkan UU No 22 Tahun 1999 tentang otonomi daerah. Otonomi daerah dalam UU No 22 Tahun 1999 yang mana kemudian diperkuat dengan amandemen UUD 1945 khususnya Pasal 18 semakin menguatkan power share antara pusat dan daerah baik dalam segi politik maupuan ekonomi.

Munculnya raja-raja kecil di daerah sebagai akibat dari diberlakukannya otonomi seluasluasnya yang termaktub dalam UU No 22 Tahun 1999 dan UU No 25 Tahun 1999 yang dengan tegas menyebutkan formulasi desentralisasi itu sendiri yaitu penyerahan wewenang pemerintah kepada daerah otonom dalam kerangka Negara Kesatuan Republik Indonesia. Ketentuan ini kemudian semakin dikonkritkan dalam Pasal 7(1) yang mengatur tentang konsep dasar relasi kewenangan antara pemerintah pusat dan daerah. Secara singkat disebutkan bahwa "kewenangan daerah mencakup kewenangan dalam seluruh bidang pemerintahan, kecuali kewenangan dalam bidang politik luar negeri, 
pertahanan keamanan, peradilan, moneter dan fiscal, agaman serta kewenangan bidang lain.

\section{Masa 2004 - Sekarang}

Dengan selesainya proses amandemen UUD 1945 tahap ke empat pada 2002 membawa dampak juga dengan perubahan undangundang otonomi daerah.UU No 22 Tahun 1999 yang lebih bernuansa federalis dengan melahirkan raja-raja kecil di daerah dirubah dengan UU No 32 Tahun 2004 tentang pemerintah daerah.Berdasarkan UU No 32 Tahun 2004 tentang pemerintahan daerah, desa diatur mulai dari pasal 200 sampai dengan pasal 216.

Dalam Pasal 200 ayat(1)

menyebutkan bahwa "Dalam pemerintahan daerah kabupaten/ kota dibentuk pemerintahan desa yang terdiri atas pemerintah desa dan badan permusyawaratan desa."

Kemudian lebih lanjut UU No 32 Tahun 2004 Pasal 207 juga menyebutkan bahwa "Tugas pembantuan dari pemerintah, pemerintah provinsi, dan/atau pemerintah kabupaten/kota kepada desa disertai dengan pembiayaan, sarana dan prasarana, serta sumber daya manusia."

Hal ini semakin menunjukkan perhatian pemerintah pusat kepada daerah khususnya desa. Realita ini yang mebedakan antara era orde baru dengan orde reformasi dimana keberlakuan otonomi daerah tetap dalam koridor NKRI dengan menitik pusatkan perhatian pada kemandirian masyarakat khususnya di daerah pedesaan.

\subsection{Arah Politik Hukum \\ Pemerintahan Desa}

Politik hukum atau legal policy pemerintahan desa dari tahun ke tahun semakin menunjukkan kearah pembentukan civil society atau meminjam istilah Nurcholis Madjid “masyarakat madani".Politik hukum pemerintahan desa yang dimaksud disini adalah arah kebijakan hukum pemerintahan desa secara nasional, yakni garis-garis besar kebijaksanaan hukum yang dianut oleh penyelenggara negara dalam usaha dan upaya memelihara, memperuntukkan , mengambil manfaat, mengatur dan mengurus pemerintahan desa beserta masyarakat desa sebagai komunitas yang mengatur dirinya sendiri.

Hal ini telah nampak dengan dikeluarkannya Peraturan Pemerintah Nomor 72 Tahun 2005 tentang desa sebagai ganti dari undang-undang nomor 5 tahun 1979 tentang pemerintahan desa. Dalam PP ini menurut Prof Ateng dan Suprin $^{17}$ telah mempunyai pemikiran tentang pengaturan mengenai desa yaitu:

1. Keanekaragaman yang memiliki makna bahwa istilah desa dapat disesuaikan dengan asal-usul dan kondisi social budaya masyarakat setempat. Hal ini berarti pola penyelenggaraan pemerintahan serta pelaksanaan pembangunan di desa harus menghormati sistem nilai yang berlaku pada masyarakat setempat,tetapi juga harus tetap mengindahkan sistem nilai bersama dalam kehidupan berbangsa dan bernegara.

2. Partisipasi, memiliki makan bahwa penyelenggaraan pemerintahan dan pembangunan desa harus mampu mewujudkan ${ }^{17}$ Ateng Syafrudin dan Suprin.Op.Cit.hlm
$88-89$ 
peran aktif masyarakat agar masyarakat senantiasa memiliki dan turut serta bertanggungjawab terhadap perkembangan kehidupan bersama sesame warga desa

3. Otonomi asli, memiliki makna bahwa kewenangan pemerintah desa dalam mengatur dan mengurus masyarakat setempat didsarkan pada hak asal ususl dan nilai-nilai social budaya yang terdapat pada masyarakat setempat, tetapi harus diselenggarakan dalam prespektif administrasi pemerintahan negara yang selalu mengikuti perkembangan zaman.

4. Demokratisasi, memiliki makna bahwa penyelenggaraan pemerintahan dan pelaksanan pembangunan di desa harus mengakomodasi aspirasi masyarakat yang diartikulasikan dan diagregarsikan melalui BPD dan lembaga kemasyarakatan sebagai mitra pemerintahan desa.

5. Pemberdayaan masyarakat, memiliki makna bahwa penyelenggaraan pemerintahan dan pelaksanaan pembangunan di desa ditujukan untuk meningkatkan taraf hidup dan kesejahteraan masyarakat melalui penetapan kebijakan, progam dan kegiatan yang sesuai dengan esensi masalah dan prioritas kebutuhan masyarakat.

Secara umum, Ateng Syarifudin $^{18}$ berpendapat bahwa politik hukum pemerintahan desa

\footnotetext{
${ }^{18}$ Ateng Syarifudin dalam Ateng Syarifudin dan Suprin Na'a.Op.Cit.hlm.90-91
}

yang paling mutakhr adalah sebagai berikut:

1. Desa atau yang disebut dengan nama lain adalah suatu keatuan masyarakat hukum yang mempunayi susunan asli berdasarkan hak asal-usul yang bersifat istimewa, sebagaimana dimaksud dalam pasal 18 UUD 1945. Landasan pemikiran dalam pengaturan mengenai pemerintahan desa adalah keanekaragaman, partisipasi, otonomi asli, demokrasi dan pemberdayaan masyarakat;

2. Penyelenggaraan pemerintahan desa merupakan sub sistem dari sistem penyelenggaraan pemerintahan sehingga desa memiliki kewenangan untuk menagtur dan mgurus kepentingan masyarakatnya. Kepala desa bertanggungjawab pada badan permusyawaratan desa dan menyampaikan laporan pelaksanaan tugas tersebut kepada bupati/walikota.

3. Desa dapat melakukan perbuatan hukum, baik hukum public maupun hukum perdata, memiliki kekayaan, harta benda, dan bangunan serta dapat dituntut dan menuntut di muka pengadilan. Untuk itu kepala desa dengan persetujuan BPD mempunyai wewenang untuk melakukan perbuatan hukum dan mengadakan perjanjian yang saling menguntungkan.

4. Sebagai perwujudan demokrasi, di desa dibentuk BPD atau sebutan lain yang sesuai dengan budaya yang berkembang di desa yang bersangkutan, yang berfungsi sebagai lembaga legislasi dan 


pengawasan dalam hal
pelaksanaan peraturan desa,
anggran pendapatan dan
belanja desa, peraturan kepala
desa dan keputusan desa.

5. Di desa dibentuk lembaga masyarakat desa lainnya sesuai dengan kebutuhan desa. Lembaga dimaksud merupakan mitra pemerintah desa dalam rangka pemeberdayaan masyarakat desa.

6. Desa memiliki sumebr pembiayaan berupa pendapatan desa, bantuan pemerintah dan pemerintah daerah, pendapatn lain-lain yang sah, sumbangan pihak ketiga dan pinjaman desa.

7. Berdasarkan hak asal-usul desa yang bersangkutan, kepala desa mempunyai wewenang untuk mendamaikan perkara / sengketa dari para warganya.

8. Dalam upaya meningkatkan dan mempercepat pelayanan kepada masyarakat yang bercirikan perkotaan dibentuk kelurahan yang berada di dalam daerah kabuoaten/kota.

\section{Penutup}

\subsection{Kesimpulan}

1. Bahwa perubahan undangundang tentang otonomi daerah sangat tergantung dari situasi dan arah politik yang dianut oleh pemerintahan yang berkuasa. Jika arah politik pemerintah yang berkuasa adalah responsive, maka akan menghasilkan perundangundangan yang bercorak demokratis, namun sebaliknya jika arah politik pemeritah yang berkuasa adalah otoriter, maka akan menghasilkan perundangundangan yang bercorak konserfativ atau otoriter.

2. Bahwa arah politik hukum pemerintahan desa dari tahun ke tahun telah menunjukkan kearah yang lebih baik. Sebagai bagian sistem pemerintahn terkecil desa telah memiliki peraturannya sendiri yaitu melalui Peraturan Pemerintah Nomor 72 Tahun 2005 tentang desa. Hal ini adalah sebagai dasar bahwa sistem organisasi desa langsung dibawah bupati atau walikota.

\subsection{Saran}

1. Hendaknya kedepan perlu memecah undang-undang 32 Tahun 2004 tentang pemerintahan daerah menjadi tiga bagian yaitu undang-undang tentang pemerintah daerah, undang-undang tentang pemilukada dan undang-undang tentang desa. Hal ini bertujuan untuksemakin menguatkan pemerintahan desa dalam mengeluarkan kebijakan dalam pengelolaan desa.

2. Hendaknya dengan semakin diperhatikannya pemerintahan desa oleh pusat, maka diperlukan pembenahan SDM agar mampu menerjemahkan setiap perintah undang-undang. Jangan sampai karena minimnya SDM, undang-undang yang sudah dibuat hanya sekedar pajangan karena tidak mampu menerjemahkannya dalam sebuah kebijakan yang pro rakyat. 


\section{Daftar Pustaka}

Ateng Syarifuddin, 2010, Republik

Desa, Alumni:Bandung

Bagir Manan,1993, Perjalanan

historis Pasal 18 UUD 1945,

Uniska:karawang

Didik Sukaryono, 2010,

Pembaharuan Hukum

Pemerintah Desa, Setara

Press:Malang

HAW.Widjaja,2012, Otonomi Desa

(Merupakan Otonom yang Asli,

Bulat dan Utuh), Rajawali

Press:Jakarta

Imam Syaukani, dan A.Ahsin

Thohari, 2006, Dasar-dasar

Politik Hukum, Raja Grafindo

Persada: Jakarta

Miriam Budiardjo, 2010. Dasardasar ilmu politik. edisi revisi, Gramedia:Jakarta

Mahfud M.D, 1998. Politik Hukum

di Indonesia, LP3ES:Jakarta 2010, Membangun

Politik Hukum, Menegakkan

Konstitusi, Rajawali Press:

Jakarta

Sadjijiono, 2008, Memahami

Beberapa Bab Pokok Hukum

Administrasi, Laksbang

Pressindo: Yogyakarta

Sri Soemantri Martosoewignjo, 1992, Bunga Rampai Hukum

Tata Negara Indonesia,

Alumni:Bandung

Tim Penyusun kamus Pusat Pembianaan dan Pengembangan Bahasa, 1995, Kamus Besar Bahasa Indonesia Cet.VII, Balai Pustaka:Jakarta

Yulia Netta dan M.Iwan Satriawan, 2013, Ilmu Negara (Dasar-Dasar Teori Bernegara), PKK-PUU FH Unila: Bandar Lampung 